O “DICUMÊ” ESTÁ PRONTO! A INFLUÊNCIA DAS PRÁTICAS ALIMENTARES DA NOVA COZINHA NO COTIDIANO DOS HABITANTES DA FAZENDA PRAZERES - BERTOLÍNIA, PIAUÍ

"DICUMÊ" IS READY! THE INFLUENCE OF FOOD PRACTICES IN THE NEW KITCHEN IN THE DAYLE OF THE RESIDENTS OF THE PRAZERES FARM BERTOLÍNIA, PIAUÍ

Ana Joaquina da Cruz Oliveira

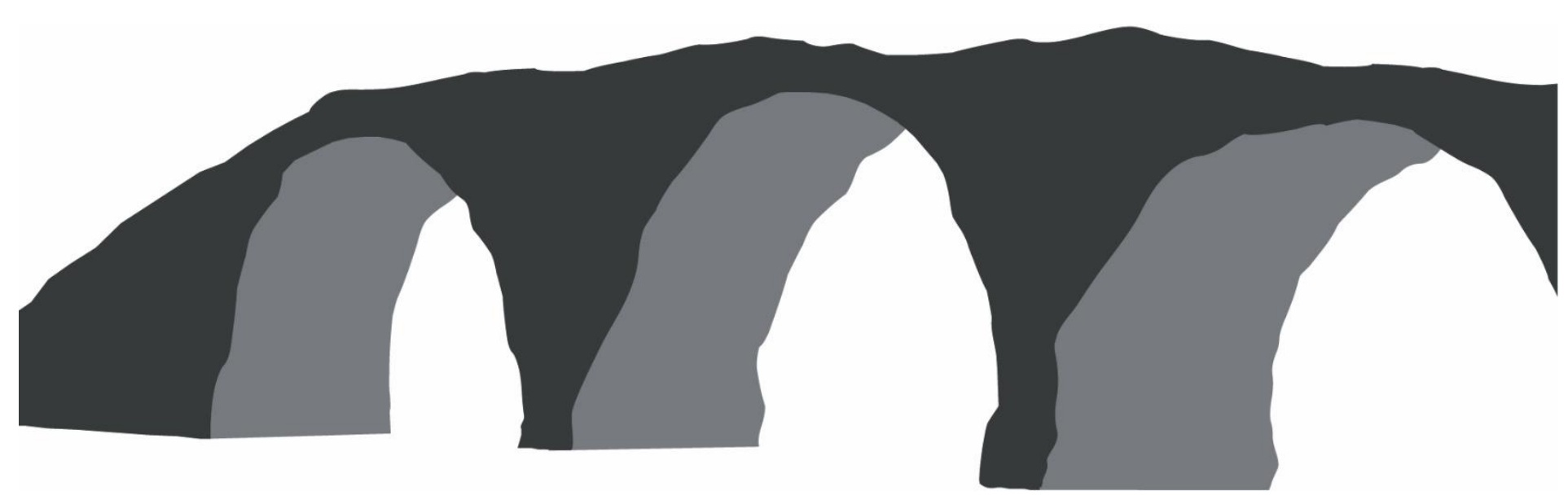




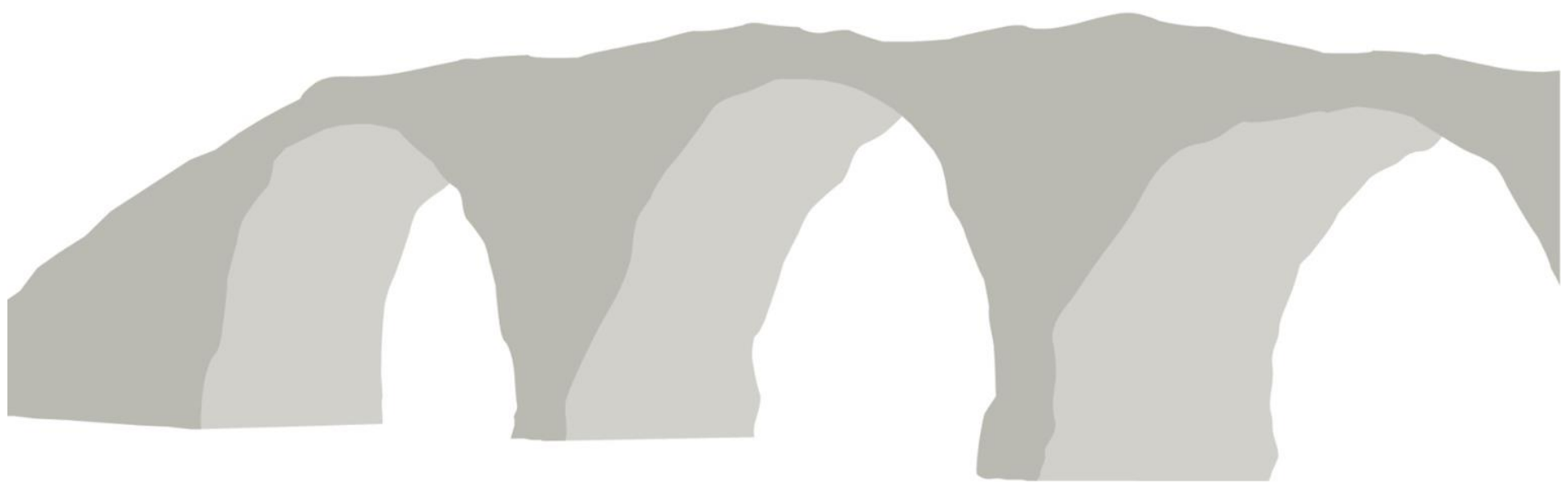

Data de recebimento: 07/01/2019.

Data de aceite:04/05/2019. 


\section{O “DICUMÊ” ESTÁ PRONTO! A INFLUÊNCIA DAS PRÁTICAS \\ ALIMENTARES DA NOVA COZINHA NO COTIDIANO DOS HABITANTES \\ DA FAZENDA PRAZERES - BERTOLÍNIA, PIAUÍ}

\section{"DICUMÊ" IS READY! THE INFLUENCE OF FOOD PRACTICES IN THE NEW KITCHEN IN THE DAYLE OF THE RESIDENTS OF THE PRAZERES FARM - BERTOLÍNIA, PIAUÍ}

Ana Joaquina da Cruz Oliveira ${ }^{1}$

\section{RESUMO}

As práticas alimentares são parte integrante de uma sociedade e, portanto, se constituem como meio para compreendermos relações sociais. Essa ação que realizamos cotidianamente sofreu alterações significativas ao longo do tempo, dentre as mais expressivas, cito o surgimento da Nova Cozinha, que modificou essa atividade em todas as suas etapas e conformou muitos dos nossos hábitos atuais. Esse foi o enfoque utilizado para estudar a cultura material, especificamente as louças, advindas do sítio arqueológico Fazenda Prazeres. O objetivo principal da pesquisa foi compreender como esse grupo incorporou as mudanças sociais e culturais que ocorreram durante o século XIX, moldando suas regras de consumo e de comensalidade.

Palavras-chave: Nova Cozinha, Fazenda Prazeres, Arqueologia.

\section{RESUMEN}

Las prácticas alimentarias son parte integrante de una sociedad y, por lo tanto, se constituyen como medio para comprender relaciones sociales. Esta acción que realizamos cotidianamente sufrió cambios significativos a lo largo del tiempo, entre los más expresivos, cito el surgimiento de la Nueva Cocina que modificó esta actividad en todas sus etapas y conformó muchos de nuestros hábitos actuales. Este fue el enfoque utilizado para estudiar la cultura material, específicamente las vajillas, provenientes del sitio arqueológico Fazenda Prazeres. El objetivo principal de la investigación fue comprender cómo ese grupo incorporó los cambios sociales y culturales que ocurrieron durante el siglo XIX moldeando sus reglas de consumo y de comensalidad.

Palabras clave: Nueva Cocina, Hacienda Prazeres, Arqueología.

\footnotetext{
${ }^{1}$ Mestre em Arqueologia, Universidade Federal do Piauí (UFPI), ana.oliveiracruz@gmail.com. https://orcid.org/0000-0001-7143-9975.
} 


\section{ABSTRACT}

Eating practices are an integral part of a society and therefore constitute a means for understanding social relations. This daily activity has undergone significant changes over time, among the most expressive of them, the emergence of the New Kitchen that modified food practices in all its stages and conformed many of our current habits. This was the focus used to study the material culture, specifically the tableware, coming from the archaeological site Fazenda Prazeres. The main objective of the research was to understand how this group incorporated the social and cultural changes that occurred during the nineteenth century, shaping its rules of consumption and commensality.

Keywords: New Kitchen, Fazenda Prazeres, Archaeology. 


\section{INTRODUÇÃO}

As mudanças ocorridas no mundo a partir do século XVIII não se limitaram ao campo político e econômico, atingiram também a esfera cotidiana, em particular, as práticas alimentares. Intitulada de Nova Cozinha, essa nova maneira de pensar a alimentação alterou as práticas alimentares em todas as suas etapas, aquisição, preparação, apresentação e consumo dos alimentos, conformando nossos hábitos atuais. De maneira mais específica, essas inovações integraram os processos de transformação que consolidaram o chamado Mundo Moderno (Marschoff, 2007).

Embora tenha tido origem na Europa, esse fenômeno ocorreu de maneira globalizada e influenciou tanto na elaboração dos banquetes como no comportamento à mesa e na aquisição de todo um aparato material, como louças e mobiliário para dar suporte às novas práticas. No Brasil, a introdução desses hábitos aconteceu através dos europeus que aqui chegavam, mas, sobretudo, a partir da vinda da família real e da instalação da corte na cidade do Rio de Janeiro, se tornando um modelo de comportamento a ser seguido principalmente pelas classes mais abastadas. Contudo cabe ressaltar que a apropriação desses costumes não ocorreu de maneira uniforme em todas as regiões brasileiras (Soares \& Corção, 2012)

Entretanto, a tendência de muitos pesquisadores foi buscar homogeneizar a forma com que as sociedades incorporaram essas transformações que aconteceram em escala global, rotulando, muitas vezes, determinados grupos que não adotaram tais comportamentos como atrasados, alheios ou periféricos (Souza,2015). Dessa forma, ignoraram a agência e as particularidades dos indivíduos no processo de aceitação, negação ou adaptação dessas novas práticas e condutas, encontrando maneiras próprias de se integrar ao Mundo Moderno ou resistir a ele.

No caso do Piauí, principalmente em razão das especificidades do processo de colonização de seu território e de formação de sua sociedade, criou-se entre alguns pesquisadores uma concepção generalista de que a inadequação do sertanejo aos padrões e valores europeus se dava pela ignorância e pela rusticidade das pessoas (Souza,2015). Além disso, que a presença quase inexistente de alguns bens característicos desse processo, como por exemplo, mobiliário e produtos manufaturados, abundantes em outros contextos como os engenhos de cana-de açúcar, se deu pelo fato de que a "civilização do couro" não possuía recursos financeiros suficientes para adquiri-los (Brandão, 1995, Goulart, 1966).

Esse pensamento homogeneizante foi reforçado em documentos oficiais como os relatórios de presidentes de Província e por relatos de viajantes e memorialistas. Além disso, esse rótulo do atraso e da estagnação também acabou enraizado no senso comum, perdurando ainda no presente, caracterizando-se como o que Souza (2015) denomina de história única, ou seja, estereótipos que, mesmo não sendo totalmente inverídicos, são incompletos, fazendo com que uma história se torne a única história.

Assim, entendendo que esse processo foi incorporado de maneira diferente pelos grupos sociais, ao desenvolver minha pesquisa de mestrado intitulada A Comida Está Servida! Um Estudo Das Práticas Alimentares Na Fazenda Prazeres, Bertolínia - PI, da qual deriva esse artigo, estabeleci como objetivo principal buscar compreender quais estratégias particulares a elite colonial piauiense desenvolveu para se integrar à modernidade. De maneira particular, para desenvolver a pesquisa junto com minhas orientadoras, optei dentre as diversas mudanças sociais, culturais e econômicas que ocorreram entre a metade do século XVIII e o século 
O “DICUMÊ” ESTÁ PRONTO! A INFLUÊNCIA DAS PRÁTICAS ALIMENTARES DA NOVA COZINHA

NO COTIDIANO DOS HABITANTES DA FAZENDA PRAZERES -BERTOLÍNIA, PIAUÍ

XIX, por explorar as práticas alimentares, tendo em vista que elas se configuram como uma prática cultural e, portanto, se constituem como mecanismo para compreendermos as relações sociais entre os indivíduos.

De maneira mais específica, selecionamos os artefatos de louça como meio para compreender essas mudanças, levando em conta dois fatores: sua abundância no registro arqueológico do sítio e por ter sido uma das grandes transformações trazidas pela Nova Cozinha, denominação utilizada para se referir a esses processos de mudança na preparação, apresentação e consumo dos alimentos que ocorreram a partir do século XVIII. Cabe ressaltar que a Fazenda Prazeres foi uma unidade residencial rural ocupada entre o final do século XVIII, meados do século XX. No contexto de sua formação, pertencia a Jerumenha, uma das primeiras regiões a serem ocupadas pelos colonizadores que chegaram ao território piauiense. Além disso, seus proprietários tiveram grande relevância social, econômica e política na região com reflexos até a atualidade.

Devido ao seu potencial informativo acerca da ocupação dessa região e do modo de vida dos grupos sociais que ali habitaram, esse sítio arqueológico, atualmente localizado no município de Bertolínia, foi incluído no Projeto de Resgate Arqueológico no trecho da BR 135 entre os municípios de Bertolínia e Eliseu Martins, no Estado do Piauí. As escavações arqueológicas foram realizadas no ano de 2014 pela equipe da Habitus Bio Consultoria e resultaram em um acervo composto por cerca de oito mil artefatos de tipos diversos, como: louça, vidro, cerâmica, metal e osso de fauna, entre outros.

Para essa pesquisa também buscamos fundamentação teórica na Arqueologia do Mundo Moderno, que estuda a modernidade como um processo histórico e não apenas um marco temporal ou uma metodologia (Silliman e Hall, 2006), e na Arqueologia da Alimentação, abordagem que pode ser definida como "o estudo da cultura alimentar, suas representações, crenças, conhecimentos e práticas, herdadas e aprendidas, materializadas através dos vestígios arqueológicos" (Soares, 2016: 11).

Destarte a alimentação passa a ser entendida não apenas no seu sentido biológico e nutricional, mas também como uma prática cultural. O que se come? Como se come? Com quem se come? Quando se come? Em que local e de que maneira se come? De que maneira os alimentos são servidos? São questionamentos que nos permitem compreender e refletir acerca das práticas alimentares de determinados grupos bem como as questões de ordem cultural que elas carregam e que se modificaram ao longo do tempo (Marschoff, 2010a; Soares, 2016). Levamos em consideração ainda o fato de que nossas práticas alimentares não são determinadas apenas por fatores biológicos e fisiológicos, mas também por outras motivações de caráter social, como classe, idade, gênero, identidade, grupo étnico, dentre outras (Contreras \& Gracia, 2011).

Pautadas nessas definições, cruzamos os dados obtidos a partir da análise das louças com informações contidas em outras fontes escritas, como os inventários post mortem dos proprietários rurais da região de Jerumenha, confeccionados entre a segunda metade do século XVIII e o final do século XIX, os relatos de viajantes que passaram por esse território na primeira metade do século XIX e demais fontes que informassem sobre os atos cotidianos do Piauí nesse período, em especial àqueles que versavam sobre as práticas alimentares.

Este artigo tem como objetivo principal então apresentar os resultados obtidos a partir do intercruzamento dessas fontes. Assim, começo com uma breve exposição acerca das principais modificações que a Nova Cozinha proporcionou nas práticas alimentares. Em sequência, apresento uma contextualização histórica acerca da Fazenda Prazeres e dos trabalhos arqueológicos ali realizados. Por fim, trago e discuto os resultados obtidos a partir do intercruzamento dos dados contidos nas fontes descritas acima. 


\section{A NOVA COZINHA E A MODIFICAÇ̃̃O DAS PRÁTICAS ALIMENTARES}

A Nova Cozinha surgiu a partir das mudanças sociais e ideológicas que começaram a ocorrer na Europa durante o século XVIII, mais especificamente a ascensão da burguesia, o movimento iluminista, a expansão do capitalismo e a industrialização (Marschoff, 2007). Essas novas concepções ideológicas impactaram de maneira significativa a sociedade da época e resultaram na adoção de novos comportamentos que modificaram o cotidiano das pessoas e ajudaram a conformar o que denominamos de Mundo Moderno.

Esses novos comportamentos, denominados por Lima (1995:130) como “modo de vida burguês", valorizavam o individualismo, a manutenção das fronteiras entre público e privado, a ritualização da vida cotidiana, a acumulação de capital (tanto real quanto simbólico), os critérios de "respeitabilidade", a fetichização do consumo e a ascensão social. Todavia é importante ressaltar que esses hábitos não foram absorvidos de maneira passiva e homogênea por todos os grupos sociais nem por todas as localidades onde reverberaram.

Em relação às práticas alimentares, essas novas concepções influenciaram tanto dentro da cozinha, na etapa de preparação dos alimentos, quanto no serviço, na apresentação das comidas na mesa, dentre outras. Na etapa de preparação, por exemplo, instaurou-se a preocupação da Nova Cozinha em se distanciar das preparações da cozinha antiga, que eram mais homogêneas e líquidas, a partir da introdução de novos ingredientes, novas combinações e texturas, evitando os excessos de temperos e especiarias que mascaravam o sabor dos alimentos. Essas transformações estavam alinhadas à adoção de uma nova concepção acerca da natureza, vista agora como objeto de contemplação, e da sua relação com o ser humano (Marschoff, 2007, 2013).

Estendendo essa visão para os alimentos, adquiriu-se a preocupação em realizar preparações que buscassem preservar o sabor natural dos mesmos, evitando a mistura de muitos ingredientes como tipos diferentes de carnes na mesma preparação, bem como a diminuição na quantidade de condimentos e especiarias. Em relação ao consumo, a principal mudança foi na preocupação de que os pratos servidos aguçassem outros sentidos dos comensais, como a visão e o olfato, de maneira que a apresentação passou a prezar pela estética dos alimentos e pela experiência individual dos convivas (Marschoff, 2004)

As mudanças se estenderam também à adoção de um novo espaço para a realização das refeições, que separava o local onde o alimento era preparado daquele em que era consumido e que possuía mobiliário exclusivo e um elenco de objetos destinados ao consumo alimentar: a sala de jantar. Essa divisão espacial materializava também a segregação entre os grupos que ficavam na cozinha, responsáveis pela preparação e serviço, dos que sentavam à mesa e consumiam a refeição (Marschoff, 2010a; Lima, 1995).

As tendências inovadoras da Nova cozinha passaram ainda a requerer sociabilidades diferenciadas de acordo com formalização do evento em que o alimento iria ser consumido. Nesse contexto, surgiram os manuais de civilidade, que buscavam distanciar o comportamento humano do comportamento animal, "do estado de natureza”. Assim, frequentemente o comportamento humano era comparado a comportamentos animais que deveriam ser evitados, como, por exemplo, "não roer ossos como cães, não bufar repugnantemente como focas", dentre outras recomendações, como "não babar à mesa, não escarrar, não oferecer ao outro o que já havia sido mastigado, não colocar na travessa restos de alimentos parcialmente 
consumidos, não limpar os dentes com a faca ou com a toalha, não enxugar o suor ou assoar o nariz com o guardanapo" (Lima, 1995: 39).

Outra tendência observada no comportamento à mesa e incentivadas pelo "modo de vida burguês" foi a preocupação com a experiência individual e a democratização do acesso aos alimentos, na qual cada indivíduo passou a ter o direito de escolher o tipo e quantidade de alimento que desejasse, garantindo que a experiência sensorial e o gosto particular de cada um deles fossem respeitados (Marschoff, 2013).

Essa individualização das práticas alimentares pelos convivas, incentivadas pela modernidade, diferia dos hábitos alimentares do começo do século XVI, quando a experiência alimentar era coletiva, baseada no compartilhamento tanto de objetos quanto da acomodação à mesa. Os comensais eram dispostos em longos bancos de madeira e partilhavam entre si os copos e os poucos talheres existentes. No serviço, não havia a preocupação em separar a comida por tipo, todos os alimentos eram servidos em imensas travessas empilhados, podendo ser acomodadas em uma mesma porção diversas preparações, como carnes, legumes e peixes (Lima, 1995; Braudel, 1997).

A partir do século XVII, gradativamente esses costumes foram sendo substituídos. Ao mesmo tempo, novos objetos passaram a integrar a mesa de refeição, como, por exemplo, os pratos que poderiam ser fabricados em madeira ou metal, os talheres, que substituíram o uso da mão, sugerindo a agência destes enquanto mediadores entre o "estado de natureza" e o "estado de cultura", e as cadeiras individuais, que modificaram a disposição dos convidados à mesa, propiciando uma autonomia corporal maior ao convidado. Essas alterações estavam alinhadas com as ideologias recém-criadas pelo movimento iluminista (Lima, 1995; Braudel, 1995).

As transformações se refletiram também no mobiliário, especificamente daquele relacionado à sala de jantar, que passou a representar o refinamento, a civilidade e o poder do anfitrião. Os móveis, confeccionados geralmente em madeira de lei, paulatinamente se tornaram especializados e adequados às funções de exibir e guardar utensílios, expor os pratos que seriam consumidos ou apoiar os objetos que seriam utilizados naquela refeição. Passaram a figurar a partir de então nas residências móveis como os aparadores, que tinham a função de exibir as alfaias que seriam utilizadas naquela refeição, o armário louceiro ou guarda-louças, que normalmente continha portas de vidro e poderia estar localizado na sala de jantar ou na sala de visitas com o intuito de exibir os objetos requintados da família, os étageres ${ }^{2}$, consoles, buffets, credências dentre outros. Além da mobília, a sala de jantar poderia conter ainda adornos como quadros, papéis de parede, louças decorativas dentre outros adereços (Lima, 1995; Soares, 2011).

Assim como a sala de jantar, a sala de visitas também passou a funcionar como vitrine da família, tendo em vista que essas eram as áreas da casa destinadas às sociabilidades, onde havia o contato com o exterior e eram realizados os eventos formais, como o chá e o jantar (Lima, 1995). Dessa maneira, a sala de visitas também passou ser decorada com “os móveis estrangeiros e os móveis da moda (de palinha, de óleo ou de jacarandá), assim como os pianos, os espelhos, os objetos em prata, os "armários louceiros" e as cômodas com tampo de mármore" (Soares, 2011: 114).

Esse momento de transição também demandou novos objetos e tecnologias específicas para cada etapa do sistema alimentar. No caso das preparações, surgiram os fogões com uma quantidade maior de queimadores,

\footnotetext{
${ }^{2}$ Móvel de madeira normalmente decorado com ricos entalhes contendo prateleiras, portas e gavetas. Destinava-se a guardar e exibir louças, talheres e demais itens que compõe a mesa. Fonte: Dicio, Dicionário de língua portuguesa.
} 
permitindo a realização de diferentes preparações ao mesmo tempo, respeitando o prazo de cozimento de cada alimento, sem misturar, dentro do possível, sabores, odores, texturas etc. No serviço, os artefatos individuais já mencionados se tornam cada vez mais especializados como, por exemplo, pratos fundos para líquidos, pratos rasos para sólidos e pratos menores para sobremesa, além de uma infinidade de vasilhas de servir igualmente especializadas para cada tipo de preparação (Marschoff, 2007, 2013).

Foi nesse contexto que as louças assumiram o papel de protagonistas no ritual de refeição burguês, substituindo outros materiais, como a madeira e o ferro. A introdução desses artefatos se popularizou a partir do século XIX, mas eles já estavam presentes nas mesas da burguesia francesa desde o final do século XVII, época em que também chegaram ao Brasil nos navios e nos pertences dos europeus que aqui começavam a se estabelecer (Lima, 1995).

Embora gradativa, essa substituição dos artefatos de madeira e metal pela louça se alinhava com os ideais da nova cozinha, tendo em vista que as louças contribuíam para o aprimoramento visual dos alimentos devido a sua superfície clara, homogênea e lisa. Além disso, elas eram mais fáceis de limpar e possibilitavam a aquisição em maiores quantidades por um preço menor em relação aos pratos de metal, por exemplo, e permitiam a manipulação sem o risco de queimaduras, favorecendo a circulação dos objetos entre os integrantes da mesa de refeições (Marschoff, 2013).

A louça, representada a princípio pelas faianças, eram produzidas em diversos locais da Europa, entretanto foi na região inglesa de Staffordshire, no último terço do século XVIII, que ela passou a ser exportada em escala industrial para diversos países do mundo. Essa região inglesa possuía diversas manufaturas voltadas para o abastecimento interno, mas, a partir da estratégia comercial e do aprimoramento das técnicas de fabricação e decoração da louça realizada por um dos produtores da região, Josiah Wedgwood, foi que a produção alcançou uma escala global (Lima, 1995).

Diversos fatores contribuíram para essa expansão, dentre elas podemos citar o fato de que as louças produzidas por Wedgwood conseguiram conquistar a preferência da aristocracia e a própria família real por terem qualidade melhor que as faianças e um preço mais acessível que as porcelanas, despertando o desejo de outras classes sociais em adquirir esses produtos. Além disso, esse foi o período de expansão dos produtos ingleses para as colônias, permitindo que esses produtos alcançassem novos mercados consumidores (Lima, 1995).

Esse fenômeno de expansão da louça inglesa, assim como de outros itens, causando um aumento significativo nos volumes fabricados e adquiridos, tornou-se uma das características da modernidade e da expansão capitalista, sendo denominado por alguns autores como "febre ou revolução do consumo" (Araújo \& Carvalho, 1993; Lima,1995).

No caso do Brasil, a invasão de produtos manufaturados no mercado foi facilitada pela abertura dos portos em 1808 e pela transferência da corte portuguesa para o país no mesmo período, trazendo consigo os hábitos europeus que passaram a ser referência tanto na vida rotineira quanto nos eventos sociais (Lima, 1985).

Entretanto é muito importante ressaltar que esses hábitos europeus, como o consumo de chá, café, chocolate e os jantares cerimoniais que acompanharam as louças, se misturaram aos costumes brasileiros, criando maneiras particulares de se incorporar ao mundo moderno. Além disso, é importante atentar para o fato de que esses objetos não tiveram o mesmo significado em todos os contextos em que foram introduzidas (Lima, 1995; Soares e Corção, 2012; Marschoff, 2013). 
Como exemplo dessas especificidades, podemos citar o trabalho de Symanski (2002) em que ele compara sítios urbanos e os sítios periféricos de Mato Grosso, onde os proprietários, apesar de possuírem uma condição social de elite, se preocupavam menos com o refinamento das louças, com a organização da mesa e com a segmentação das refeições que as elites urbanas do Rio de Janeiro e Porto Alegre no Rio Grande do Sul. Em outro trabalho acerca de unidades domésticas do núcleo urbano de Santarém, Pará, referentes aos séculos XVIII e XIX, Symanski e Gomes (2012) discutem a mistura entre práticas alimentares europeias e indígenas, atentando para a convergência desses costumes na questão do consumo de ensopados - atividade que atuou como um denominador comum entrelaçando universos culturais distintos de origem lusa e indígena.

A partir do exposto, podemos considerar que as refeições possuíam uma importância fundamental no cotidiano da sociedade burguesa e atuavam como marcadores cronológicos da vida cotidiana. Considerando as práticas alimentares como elementos de sustentação e estruturação das práticas sociais que compunham a nova ordem social que surgia, podemos concluir que estudar o papel da louça dentro desse sistema nos permite compreender como essas práticas foram adotadas, ressignificadas ou rejeitadas em contextos distintos como é o caso da Fazenda Prazeres, localizada em Bertolínia, Estado do Piauí.

\section{A Pesquisa Histórica e Arqueológica sobre a Fazenda Prazeres}

A Fazenda Prazeres, no contexto de sua formação, integrava o termo de Jerumenha, uma das primeiras regiões piauienses a serem ocupadas pelos colonizadores no final do século XVII. Ao longo do tempo, esse território foi sendo desmembrado para constituição de novos municípios, dentre eles Bertolínia, onde atualmente a propriedade está localizada (Fig. 01). As fazendas de gado como Prazeres se constituem como uma importante fonte para compreendermos a ocupação do território piauiense e o modo de vida dos grupos que aqui habitaram, tendo em vista que elas determinaram a distribuição dos colonizadores ao longo desse espaço depois de efetuada a expulsão, preação e massacre das tribos indígenas aqui existentes. Além disso, elas desempenharam o papel de núcleo formativo da sociedade e originaram posteriormente muitas das cidades que hoje compõe o Estado do Piauí.

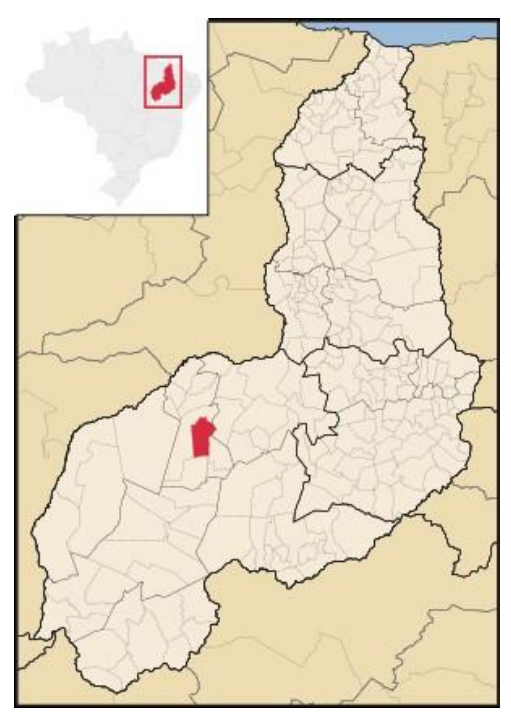

Figura 1: Mapa de Localização do Município de Bertolínia. Fonte: IBGE Cidades, 2018. 
Os dados históricos mais antigos levantados sobre Prazeres datam de 1773 e constam no inventário post mortem de João Francisco Messias, que ocupava o Juiz Ordinário de Órfãos da Vila de Jerumenha. Nesse período não são descritas edificações na propriedade, denotando, com base a organização fundiária do Piauí colonial, que ela poderia funcionar como um curral e/ou uma fazenda de criação de gado (Brandão, 1995; Mott, 1995).

Em 1816, no inventário de seu segundo proprietário, o alferes José Francisco Messias, a Fazenda Prazeres já é descrita como uma morada de casa coberta de telha com 13 portas de madeira e seis janelas. Supõe-se, portanto, que ela deve ter sido ocupada como fazenda de morada no final do século XVIII, quando o alferes, que herdou a fazenda de seu pai em 1773, contraiu matrimônio. Na ocasião do falecimento do segundo proprietário, a Fazenda, assim como a maioria dos seus bens, foi herdada por sua sobrinha e filha de criação, Antônia Maria das Neves. Contudo, por conta da prática machista e sexista da sociedade nesse período, em que a mulher era invisibilizada e considerada incapaz de gerir seu patrimônio, quem passou a administrar todos os bens do casal foi seu esposo, que também foi o testamenteiro e inventariante do alferes Messias, Gonçalo Francisco da Rocha Júnior.

Através dos relatos históricos, foi possível observar que após o falecimento do Alferes Messias, a Fazenda continuou a prosperar e teve sua sede aumentada. Essa afirmação é corroborada por pesquisadores como Silva (1991), Miranda (1996, 2017) e Costa (1999), que publicaram sobre as fazendas de gado do Piauí e destacam em seus escritos a monumentalidade da casa dessa fazenda, considerada uma das maiores e mais bem construídas do período: possuía "32 quartos, oratório, senzala, amplos alpendres, estribarias, quintal da casa e cemitério murados" (Costa, 1999: 291).

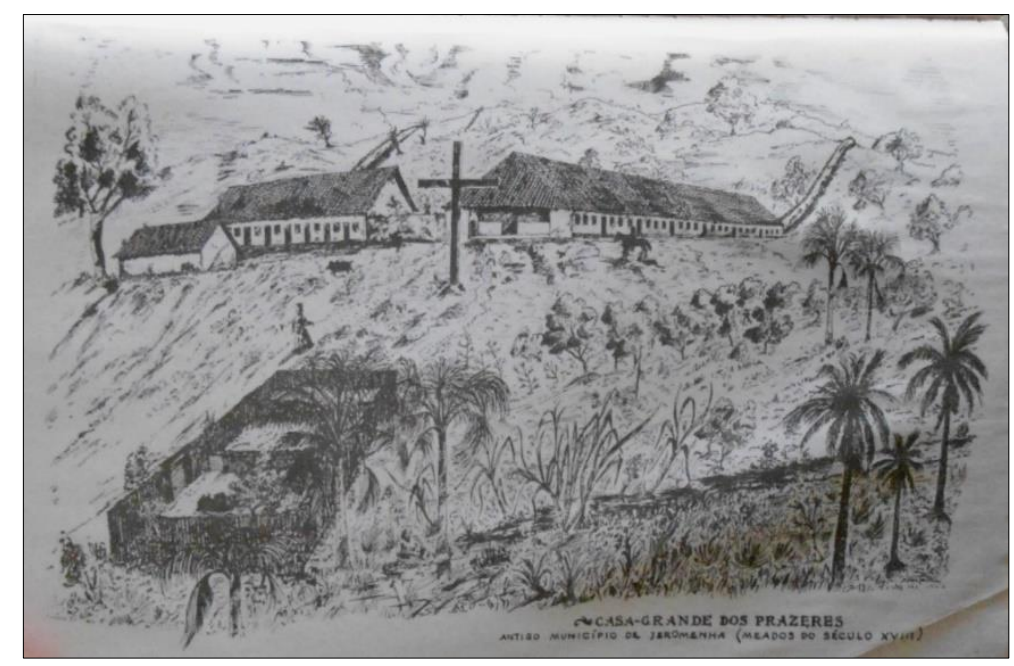

Figura 2: Ilustração da Casa Grande dos Prazeres. Fonte: Costa, 1954.

Outra descrição importante e pormenorizada que localizamos sobre a Fazenda Prazeres foi feita por George Gardner no ano de 1839:

A fazenda dos Prazeres fica em um outeiro um tanto elevado, dentro de um grande vale, cuja extremidade superior é pantanosa e cheia de buritizeiros. Nas encostas áridas das pequenas colinas que rodeiam o vale há grandes florestas daquela árvore chamada Palmeira, a que já nos referimos como sendo muito comum nos arredores de Crato; e na mata de caatinga, que atravessamos eram comuns uma ou duas espécies de palmeiras menores. Uma destas tinha o tronco bifurcado no topo, o único exemplar da 
espécie que jamais encontrei: o gomo central fora destruído por alguma causa, gerando-lhe dois galhos em seu lugar. A casa da fazenda era grande, bem construída, em tudo e por tudo a melhor que tínhamos visto desde que saímos de Oeiras. O proprietário dela, que morrera repentinamente um ano antes, parece que fora pessoa não só mais industriosa, mas também de muito melhor gosto que a generalidade dos fazendeiros do Piauí. Em torno da casa, até vasta distância, havia muitas e belas laranjeiras carregadas de frutos, que, por serem raras nesta província, nos eram grandemente preciosas. Viam-se também perto da casa grandes plantações de tanchagens e bananas, bem como alguns belos cajueiros começando a dar fruto. Por serem árvores essencialmente de beira-mar, raro se veem cultivadas no interior, sendo estas as que encontrei mais longe do litoral. A fazenda era principalmente de criação de gado, mas havia no vale, abaixo da casa, um grande canavial, de que se fabricava a rapadura, e, como o solo era favorável para o cultivo da mandioca, também esta se encontrava em quantidade (Gardner, 1975, p. 135, grifo nosso).

Nessa oportunidade, o inglês estava a caminho da Corte no Rio de Janeiro e teve que mudar sua rota, que a princípio incluía o Maranhão e o Tocantins, por conta da Balaiada, percorrendo assim diversas propriedades e paisagens piauienses, construindo um relato detalhado e muito importante do Piauí no ano de 1839. Na época da visita de Gardner, a fazenda já era administrada por Dona Antônia Maria das Neves, mais conhecida como Dona Antônia dos Prazeres, em virtude do falecimento repentino do seu esposo.

Cabe salientar que Dona Antônia, ao administrar a fazenda e permanecer viúva durante quase 40 anos, rompeu com o padrão comportamental da época, sobretudo no Piauí, que era o de que viúvas, sobretudo jovens e ricas como era seu caso, deveriam rapidamente contrair novas núpcias para ter quem administrasse seus bens (Brandão,1995). Após o falecimento da matriarca, a propriedade foi herdade por seu filho, Bertolino Alves e Rocha, que já não residia integralmente na Fazenda, alternando temporadas na Vila de Aparecida onde já estavam estabelecidos seus filhos. Com o falecimento de Bertolino em 1902, a sede da fazenda passou a ser completamente desabitada vindo a deteriorar-se com o passar dos anos.

A descoberta desse sítio arqueológico ocorreu durante o levantamento bibliográfico realizado para as pesquisas arqueológicas do Projeto de Monitoramento Arqueológico no trecho da BR 135 entre os municípios de Bertolínia e Eliseu Martins, no Estado do Piauí. Durante uma visita ao sítio, identificamos parte das ruínas da casa bem como com uma grande quantidade de material em superfície principalmente fragmentos de louça, cerâmica e material construtivo, que, por fatores antrópicos e naturais, estavam sendo expostos a diversas intempéries, de modo que optamos por inclui-lo no projeto de resgate arqueológico.

As atividades ocorreram entre os meses de setembro e novembro de 2014, se concentraram sobretudo nos arredores das ruínas identificadas como pertencentes à casa-grande e resultaram em um acervo composto por cerca de oito mil artefatos de tipos diversos, como louça, vidro, cerâmica, metal e osso de fauna entre outros. Dentre as áreas de intervenção, cabe destacar a Sondagem 01, que permitiu a evidenciação de parte do piso da Casa Grande composto por ladrilhos de barro cozido no tamanho de 20 x20 cm, tipo de "piso por excelência adotado no sertão" (Silva, 2007: 116), e a sondagem 08, caracterizada como uma área de depósito de lixo doméstico de onde foram exumados a maioria dos artefatos (Fig. 03). 

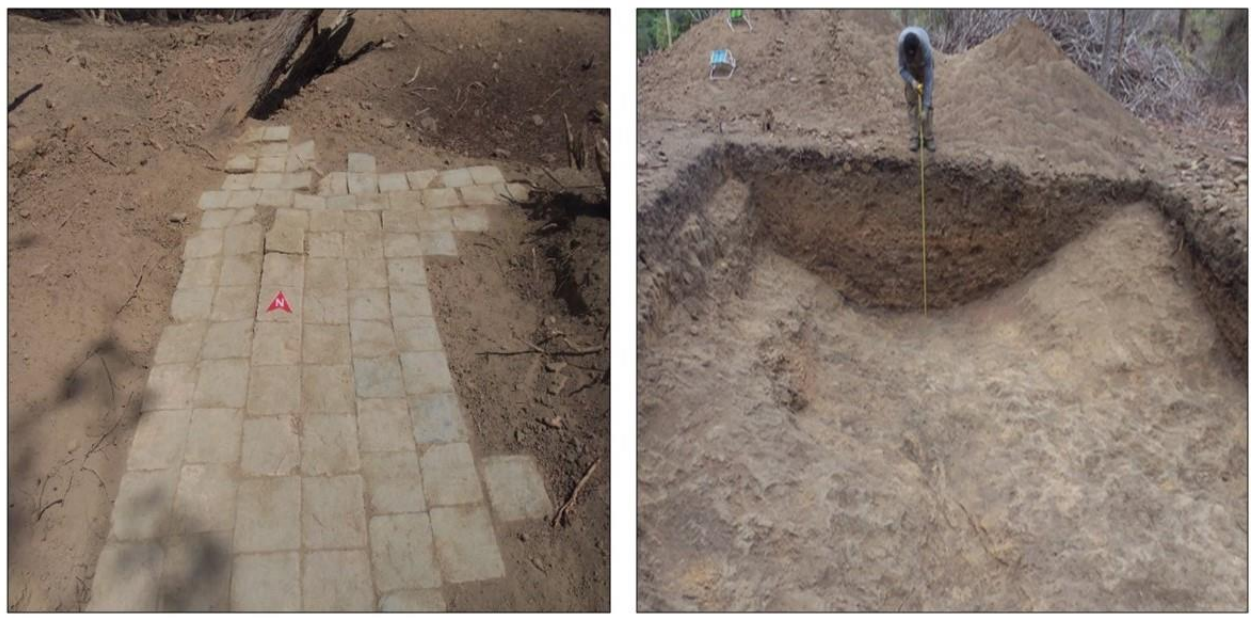

Figura 3: ’̀ esquerda o piso evidenciado na sondagem 01 e à direita base rochosa evidenciada ao final da escavação na sondagem 08. Fonte: Habitus, 2014.

\section{A COMEnSAlidade na FAZENDA PRAZERES}

A investigação arqueológica no sítio Fazenda Prazeres apontou particularidades nos comportamentos alimentares desse grupo doméstico. O acervo referente aos fragmentos de louça recuperados nesse sítio arqueológico totalizou 4067 artefatos, representando cerca de 60\% do acervo total exumado desse sítio, que é composto também por fragmentos de cerâmica, vidro, ossos de fauna, metais entre outros. Esse material estava concentrado em uma área caracterizada por uma cavidade rochosa cujos dados coletados apontam que foi aproveitada para depósito de lixo doméstico.

Para esse trabalho, as louças não foram analisadas enquanto fragmentos, mas sim a partir do NMP (Número Mínimo de Peças), tendo em vista que o objetivo principal era identificar as principais formas utilizadas nesse contexto para que pudéssemos comparar com os dados acerca das práticas alimentares desse período levantadas a partir de pesquisa bibliográfica. Para isso, os fragmentos foram comparados visando a consolidação daqueles que eram complementares e o agrupamento dos que possuíam características semelhantes denotando pertencer à mesma peça. Essa metodologia tem por objetivo, viabilizar a identificação da forma dos recipientes e auxiliar na análise do material evitando distorções na quantificação tipológica da amostra (Lima, 1989; Araújo \& Carvalho, 1993).

A partir da aferição do Número Mínimo de Peças, os artefatos foram analisados sob orientação de uma ficha cujos atributos elencados foram baseados no sistema taxonômico proposto por Majewski \& O'Brien (1987) e largamente utilizado por pesquisadores brasileiros que estudam louças históricas, como: Tocchetto et al. (2001), Tocchetto (2010), Symanski (1997), Lima (1995, 1996, 1997, 1999), Peixoto (2008), Araújo e Carvalho (1993), Soares (2011) dentre outros que inspiraram a elaboração da ficha de análise. Dessa maneira, ao estudar esses objetos, buscamos identificar principalmente os seguintes elementos: tipo de pasta, tipo de esmalte, tratamento de superfície, técnicas decorativas, decorações e tipos de peças.

Isso posto, analisamos um conjunto de 580 utensílios. A maioria deles, $86,3 \%$ (501 peças) da amostra, possuem como tipo de pasta a faiança fina, principal tipo de louça encontrado nos contextos associados ao século XIX no Brasil (Gráfico 01). Além disso, 93\% (512 artefatos) dessas peças continham algum tipo de 
decoração executada principalmente pela técnica “pintado à mão”, 53\% (272 itens), (Fig. 04) e contendo padrão shell edged (Fig. 05), o que gerou novos questionamentos, tendo em vista que normalmente, nos contextos referentes à grupos de elite, essa técnica e padrão decorativo não costumam predominar, tendo em vista que são considerados de valor intermediário pela Escala de Valores de Miller (1980) ${ }^{3}$.

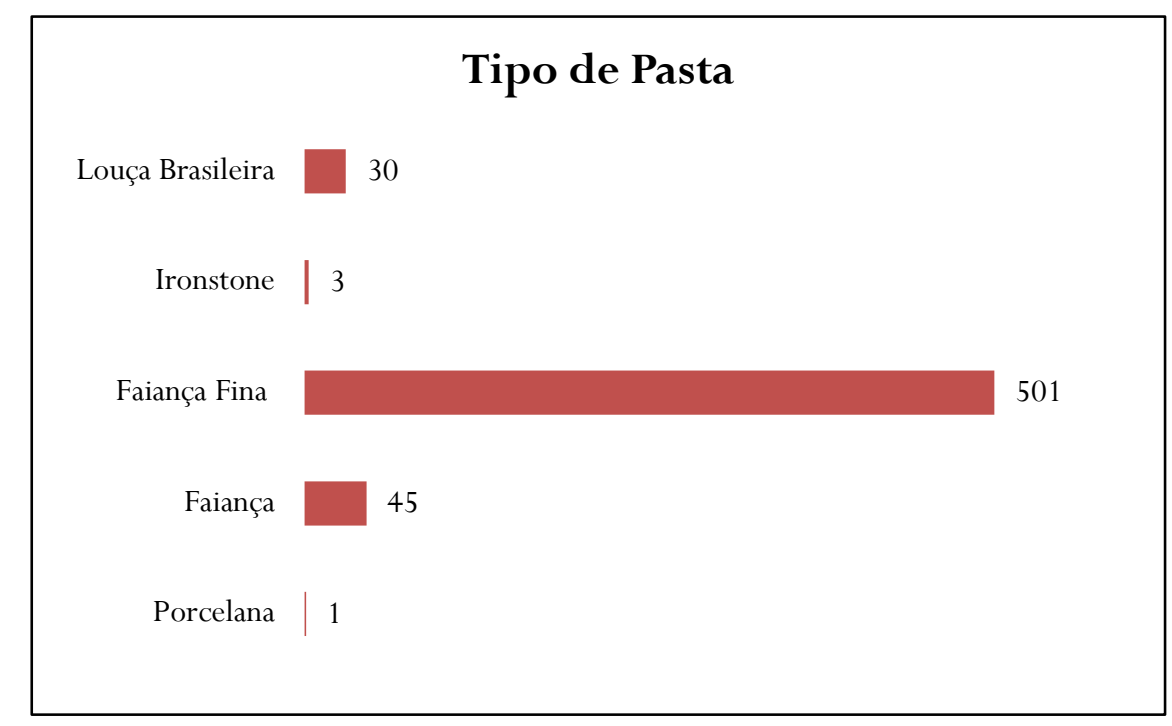

Gráfico 1: Tipo de Pasta.

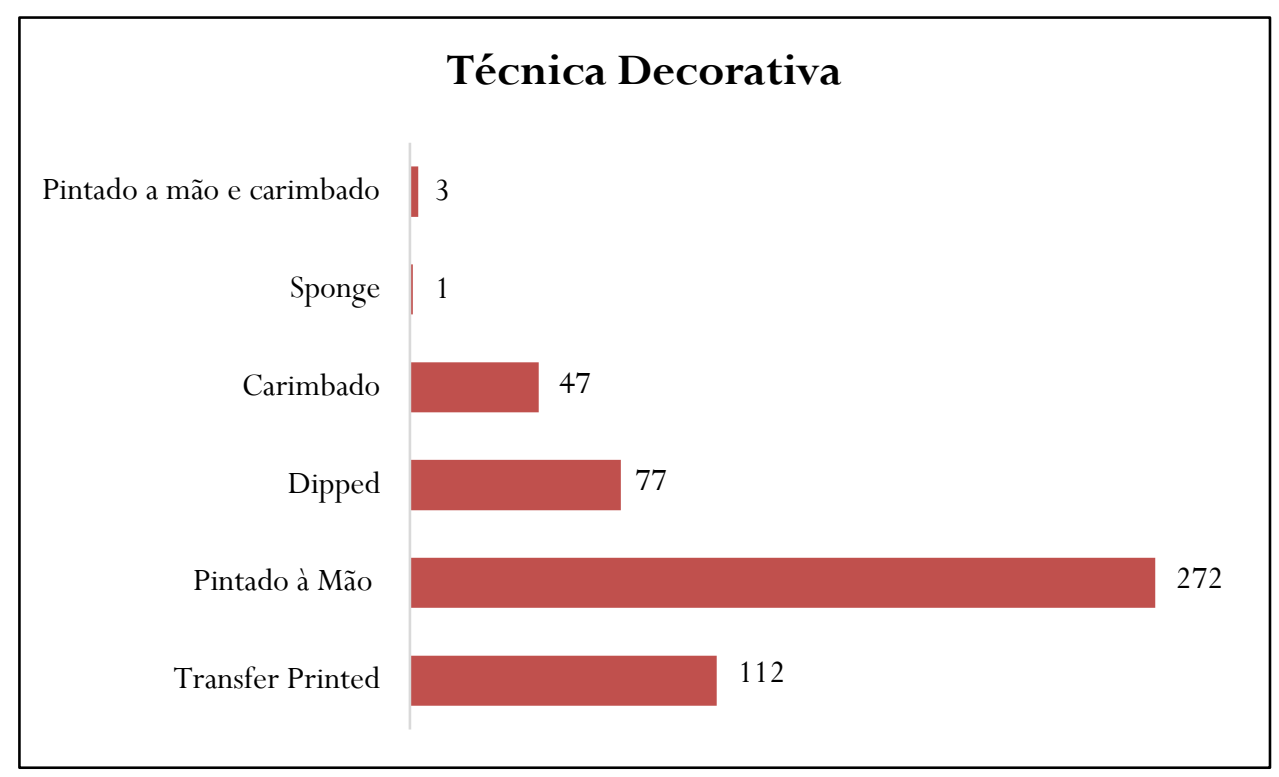

Gráfico 2: Técnica Decorativa.

\footnotetext{
${ }^{3}$ O arqueólogo George Miller criou esta ferramenta de análise na década de 1980, com base em quatro listas de preços de fabricantes de louças Staffordshire (Inglaterra) para os anos de 1796, 1814, 1833 e 1846. A partir dessas listagens, o arqueólogo estabeleceu uma escala econômica, segundo a qual os preços das louças variavam de acordo com a técnica decorativa; quanto mais complexa a técnica, mais cara a louça (Soares, 2011:87)
} 

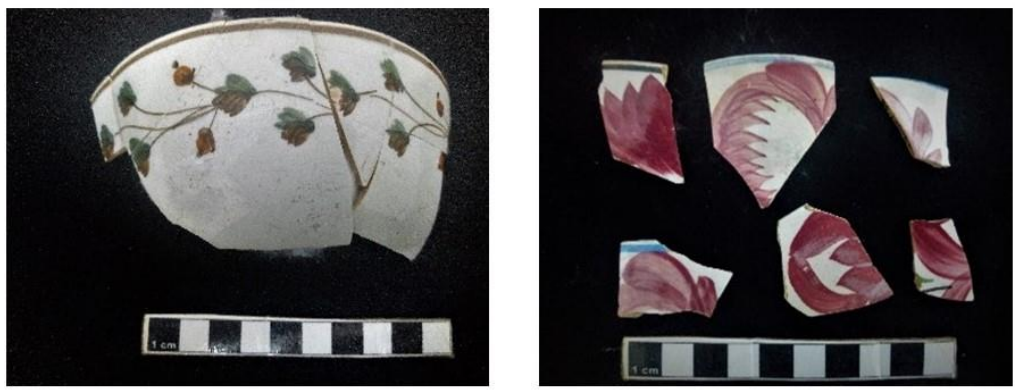

Figura 4: Artefatos decorados pela técnica "pintado à mão". Fonte: Oliveira (2018).
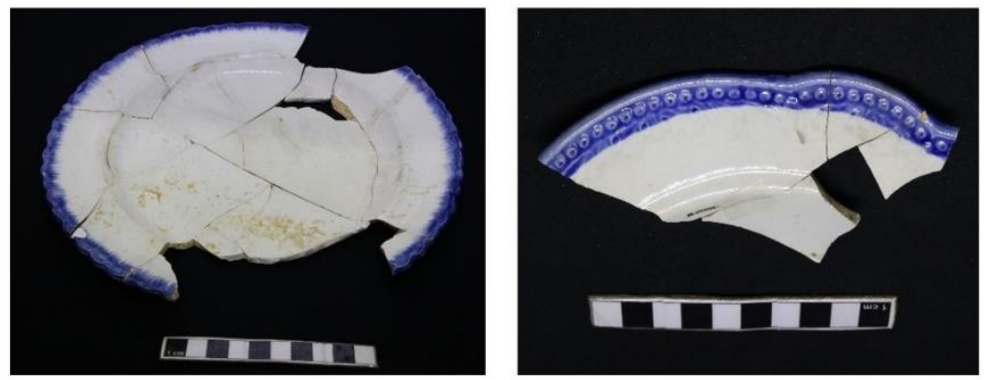

Figura 5: Pratos contendo decoração borda Shell Edged. Fonte: Oliveira (2018).

Contudo foi possível observar também a presença de itens decorados com a técnica transfer printed, 22\% (112 peças) da amostra, considerada uma técnica mais elaborada e, portanto, com um valor de mercado maior. Em geral esses itens estavam associados a serviços de chá, como xícaras, pires e pratos de doce, sendo, em alguns casos, possível identificar a formação de conjuntos ${ }^{4}$ (Fig.04). Em relação à forma, foi possível identificar um certo equilíbrio entre as planas, 53\% (290 peças) da amostra, e as formas côncavas, 46,3\% (259 peças) (gráfico 03). Esses dados obtidos a partir da análise das louças foram interpretados em conjunto com as informações levantadas nos inventários post mortem e demais fontes escritas.
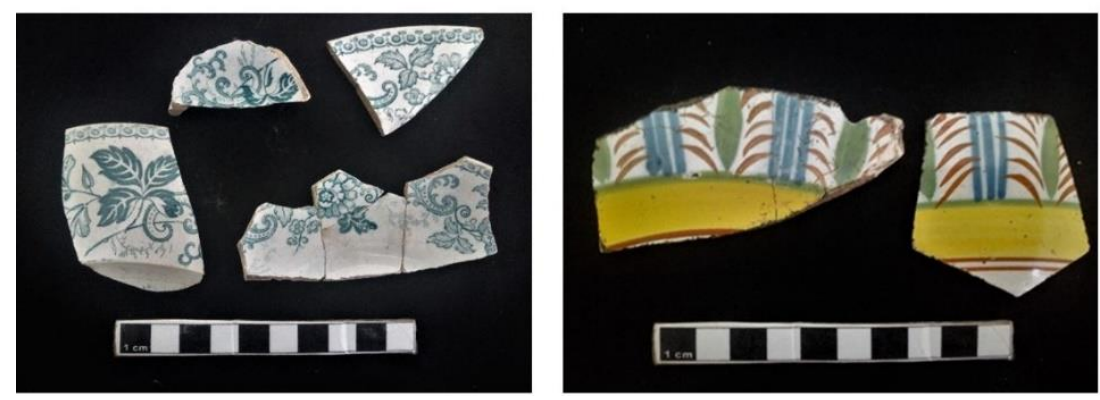

Figura 6: À esquerda, conjunto de chá decorado com técnica transfer printed, composto por uma xícara, uma malga e um prato de doce com decoração floral de cor verde, e à direita conjunto em faiança composto por uma forma plana e outra côncava contendo decoração vegetalista policrômica. Fonte: Oliveira (2018).

\footnotetext{
${ }^{4}$ Foram identificados na amostra cinco serviços de chá decorados com técnica transfer printed. O primeiro deles é composto por um pires, uma xícara e um bule, cuja decoração associa motivos geométricos com cena pastoral na cor azul; o segundo também na cor azul é composto por uma xícara, um pires e um açucareiro contendo decoração floral; o terceiro é formado por um pires, uma xícara, uma malga e um prato de doce com decoração floral de cor verde; o quarto é formado por duas xícaras e um pires na cor vermelha, associando motivos geométricos e cena exótica; e o quinto é composto por uma xícara, um pires e um prato de doce com motivo floral e cor vermelha. Além dos conjuntos de faiança fina em transfer printed, identificamos três conjuntos associados às faianças. Todos compostos por um prato e uma forma côncava que pode ser malga ou tigela todos pintados à mão com motivo vegetalista e coloração policrômica.
} 
O “DICUMÊ” ESTÁ PRONTO! A INFLUÊNCIA DAS PRÁTICAS ALIMENTARES DA NOVA COZINHA NO COTIDIANO DOS HABITANTES DA FAZENDA PRAZERES -BERTOLÍNIA, PIAUÍ

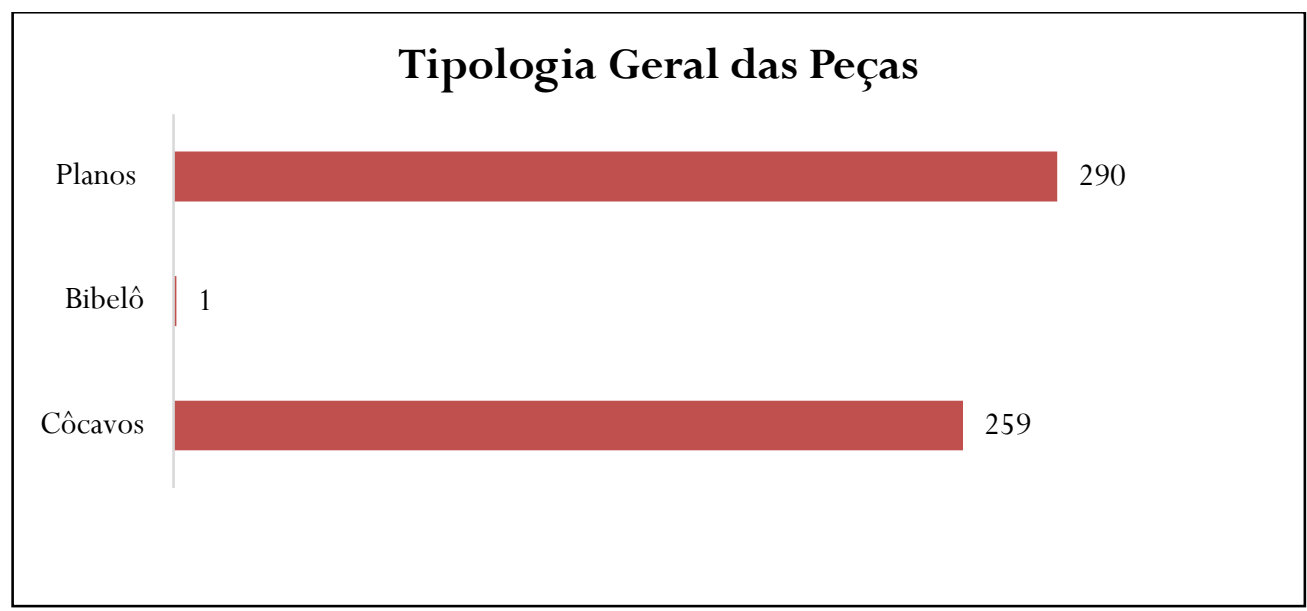

Gráfico 3: Classificação das peças quanto à forma.

Dessa maneira, observamos que a alta frequência de itens planos corrobora com as descrições de Matos (2007), Falci (2007) e Porto (1974), de que a preferência dos piauienses era, e ainda é, pelas preparações mais sólidas tanto na comida do cotidiano quanto dos dias de festa. O baião de dois (arroz misturado com feijão) e a Maria Isabel (arroz misturado com carne seca picada), pratos que integram a culinária típica do Piauí, são exemplos dessas preparações. As formas planas também representadas pelos pratos de doces ou pratos de sobremesa também corroboram com hábitos locais do consumo de bolos, queijo e doces servidos como sobremesa, merenda da tarde ou ceia.

Outro dado relevante que faz referência às formas planas é que elas pertencem ao tipo decorativo shell edge. Conforme descrevi anteriormente, baseada em Miller (1980), essa é uma categoria de louça que possuía um valor de mercado baixo e que, portanto, não corresponderia à condição econômica dos habitantes dessa propriedade. Contudo é possível considerar que a frequência elevada dos pratos em shell edge nesse registro arqueológico pode estar associada com seu uso recorrente, relacionando assim esses objetos às refeições cotidianas desse grupo.

A presença de itens como malgas e tigelas pequenas sugere o consumo de alimentos líquidos, ensopados e pastosos, como cremes e mingaus. Associando esses objetos aos hábitos alimentares piauienses descritos por Matos (2007) e Falci (2007), poderíamos relacioná-los, por exemplo, com a ingestão das coalhadas e dos doces de calda. Integram também o conjunto de formas côncavas as xícaras, que em Prazeres aparecem associadas sobretudo à técnica transfer printed, que, de acordo com Miller (1980), eram o tipo de louça mais caro abaixo da porcelana. Em outros contextos como, por exemplo, as casas oitocentistas do Rio de Janeiro estudadas por Lima (1995, 1997), a presença desses itens normalmente seria associada ao consumo do chá, hábito inglês amplamente copiado pela elite brasileira.

Entretanto, no Piauí, os relatos acerca da presença dessa bebida não são muito frequentes. Por sua vez o consumo do café é mais rememorado, tanto por pesquisadores como Porto (1974) e Matos (2007), quanto pelos viajantes que aqui passaram no início do século XIX, como George Gardner (1839) e Spix e Martius (1818). O consumo dessa bebida, tanto acompanhada por leite quanto pura, está associado ao desjejum, ao pós-almoço, à merenda da tarde e à ceia. No inventário de José Francisco Messias $(1816$,$) proprietário da$ Fazenda Prazeres, encontra-se listada uma chuculatera, espécie de chaleira de ferro ou cobre utilizada para 
passar o café, corroborando também com a hipótese de que entre os piauienses o café foi mais popular que o chá inglês.

Um fato a ser considerado é que essas peças de xícaras e pires possuem as técnicas decorativas mais caras da amostra. Certamente essas eram preferidas para os momentos de sociabilidade desse grupo doméstico diferentemente dos pratos shell edged analisados anteriormente. É provável que as xícares e pires tranfer printed estivessem sendo oferecidas aos convidados externos da residência, em momento de maior formalidade. A escolha por oferecer peças de louças consideradas as segundas mais caras do mercado nacional e internacional pode estar associada à necessidade dos anfitriões em demonstrar que conheciam as regras burguesas de etiqueta tão difundidas nacionalmente, ainda que não as seguissem no seu dia a dia.

Foi possível observar também entre a amostra de louças de Prazeres a existência de selos que confirmam a origem inglesa de peças da coleção produzidas na região de Staffordshire, Inglaterra, nas fábricas George Jones \&Sons, J\&G Meakin, J. T Close, Walker e Carter, Walker e Carter e Davenport. Além disso, há um fragmento relativo à louça francesa pertencente à Fábrica Faïenceries de Creil et Montereau.
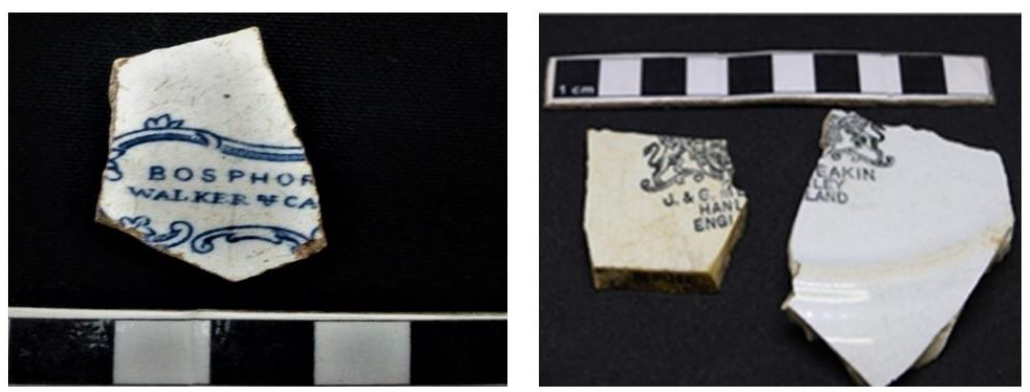

Figura 7: Exemplo de fragmentos contendo selos. À esquerda o selo Walker e Carter e à J\&G MEAKIN. Fonte: Oliveira (2018).

Possivelmente, segundo Fonseca Neto (2016), esse tipo de bem de consumo teria chegado à região de Bertolínia através da rota comercial com a cidade de Caxias, localizada no vizinho estado do Maranhão. Ou seja, apesar de distante e afastado das principais rotas comerciais, o acesso a esses bens não era impossível e nem um limitador para o grupo doméstico que habitava essa propriedade.

A própria cidade de Caxias é um exemplo de que a distância dos portos comerciais não foi um fator limitante para o acesso a produtos e hábitos dos grandes centros. Durante todo o século XIX, essa cidade é retratada por viajantes e historiadores como o grande empório do Sertão e palco de uma sociedade que buscava seguir os modos de viver europeus, adotando sociabilidades, solenidades cívicas, inaugurações, festas religiosas, exibições teatrais e saraus atreladas ao consumo de produtos importados (Pessoa, 2007).

Essas informações corroboram com as observações de Falci (2007) e Brandão (1995) de que os objetos escolhidos pela elite piauiense para demonstrar riqueza estavam mais relacionados a artigos de montaria, como as selas da Bahia ou selins ingleses ricamente decorados muito presentes nos inventários, ou artigos como redes e enxovais de linho e algodão. Além disso, os principais bens utilizados para avaliar o patrimônio de uma família eram as fazendas e os rebanhos de gado vacum.

Outra particularidade relacionada às práticas alimentares nas fazendas piauienses do século XIX diz respeito ao local onde as refeições eram consumidas. Em muitos contextos brasileiros desse período, tanto rurais, como os engenhos de cana-de-açúcar estudados por Barbosa (2012), quanto urbanos, como as residências cariocas e porto-alegrenses estudadas respectivamente por Lima (1995, 1997) e Symanski (1997), 
existia um cômodo especial para a realização das refeições: a sala de jantar. O surgimento desse compartimento também está relacionado com as tendências da Nova Cozinha, que pregava a separação entre o local onde os alimentos seriam preparados daquele onde os mesmos seriam consumidos. De forma concomitante, a sala de jantar passou a funcionar como a vitrine da casa onde eram exibidos os móveis, a decoração e as alfaias da família. (Lima, 1995).

De acordo com Lemos (1993:103 apud Symanski, 2002), antes de se tornar esse espaço público de sociabilidades, "a sala de jantar, até o começo do século XIX, era a tradicional varanda colonial, um local alpendrado nos fundos da casa, espaço íntimo e multifuncional, no qual a família fazia suas refeições e permanecia nos momentos de lazer e de trabalho caseiro". Além da função de separar o espaço de preparação do espaço de consumo dos alimentos, a varanda colonial servia como demarcador espacial, tornando visível, especialmente, a hierarquia entre os grupos que conviviam naquele espaço, onde os patrões comem na mesa de refeições e os agregados na cozinha (Pereira, 2007).

Nas fazendas piauienses, a varanda colonial não se transformou em sala de jantar, mantendo-se como a varanda de refeições. A mobília desse cômodo, em geral, permaneceu simples. Conforme relatam os inventários analisados, não se utilizavam aparadores, buffets ou etágeres, mas sim uma mesa de madeira com um banco igualmente de madeira ou cadeiras, que poderiam ser forradas com couro, uma bilheira para acomodar os potes de água e um armário para guardar a louça e os talheres. Esse espaço era utilizado ainda para realização das sociabilidades domésticas, principalmente femininas, nas quais patroas e empregadas se juntavam para realização de tarefas como gomar roupa, debulhar feijão, fiar ou costurar (Pereira, 2007).

Enquanto a sala de jantar ilustrava a ritualização das práticas cotidianas pregada pelo modo de vida burguês nas capitais brasileiras; nas quais as refeições eram cercadas de regras, etapas e artefatos, dentre eles as louças, que costumavam ser escolhidas com muito esmero; a varanda das refeições sugere uma menor ritualidade no consumo de comidas nessa região do Piauí colonial, utilizando móveis e louças simples, baratas e funcionais, ao menos nos eventos mais cotidianos.

Nesse sentido, acredito que as refeições nessa unidade doméstica fossem feitas com maior informalidade, negando as regras de etiqueta tão presentes entre a elite nacional. Embora existam conjuntos, especialmente em transfer printed, possivelmente para serem utilizados em ocasiões especiais, nota-se a preferência por itens mais funcionais, que pudessem ser utilizados em mais de uma refeição (destaca-se a ausência de itens específicos de louças, como, por exemplo, molheiras, cremeiras, azeitoneiras dentre outros). A análise dos inventários post mortem dos proprietários da Fazenda Prazeres e do senhorio da região de Jerumenha também corroboram com essa hipótese, pois não listam conjuntos ou aparelhos de louça, sempre aparecem itens funcionais e sem muitos detalhes decorativos.

Por outro lado, esses documentos descrevem a presença de outros itens manufaturados relacionados com as práticas cotidianas e itens pessoais, como exemplo podemos citar itens do inventário de José Francisco Messias (1816), proprietário de Prazeres: um colete de droguete preto, um chapéu de sol, um calção de casimira branca, uma casaca de pano verde, meias de algodão e uma bengala de cana da índia, itens, que de acordo com Araújo (2004), compunham o vestuário do homem moderno. Além disso, são listados metais preciosos como ouro e prata e itens de montaria, como selins ingleses, selas da Bahia, esporas e bridas. Ou seja, a não ostentação do seu poder econômico através de louças caras não se deu por falta de poder aquisitivo, mas sim uma escolha; já que outros itens de consumo considerados modernos e manufaturados fizeram parte dos bens desse proprietário. 
Essa descrição demonstra que a pressuposição que se costuma fazer de que diferentes grupos sociais assimilaram passivamente modelos e padrões de comportamento da elite desconsidera a agencia desses grupos na tomada de decisões e escolhas de consumo, nos fazendo questionar se, de fato, algum dia chegamos a ser modernos, ao menos no que se refere à alimentação e essa região do país.

\section{CONSIDERAÇÕES FINAIS}

As práticas sociais de um grupo são responsáveis por estabelecer e manter as relações sociais, criando uma complexa rede que permite a interação entre os indivíduos entre si e com sua cultura material (Cruz, 2011). Dessa forma, considerar a alimentação como uma prática social é afirmar que ela se constitui em um mecanismo para se compreender como se estruturaram as relações sociais dentro de um determinado contexto. Além disso, por se tratar de uma atividade diária e imperativa que compartimenta o tempo e as atividades dos indivíduos, se configura como uma forma de compreender o cotidiano de um determinado grupo.

A prática alimentar também é um fenômeno dinâmico e sofreu mudanças profundas com o intercâmbio de alimentos e hábitos comensais, fazendo com que cada sociedade encontrasse uma forma própria de se integrar ao Mundo Moderno. Um dos principais fenômenos desse período na alimentação, denominado de Nova Cozinha, alterou o sistema alimentar materializando novas formas de obtenção do alimento, novos preparos, produtos, combinações e tecnologias.

Nesse contexto, as louças passaram a compor a mesa de diferentes segmentos da sociedade durante o século XIX, tanto no Brasil quanto na Europa. Esse foi um dos motivos de escolhermos essa categoria material, afim de investigar qual papel elas desempenharam nesse processo e quais significados sociais esses objetos possuíam para aquelas pessoas. Cabe ressaltar que toda essa análise foi pautada na concepção de que, mesmo se tratando de um fenômeno globalizado, os ideais e as práticas modernas foram assimiladas de maneira distintas por cada grupo social.

No Piauí, pela formação essencialmente rural de sua sociedade, tendenciosamente interpretou-se que seus habitantes não tiveram acesso à modernidade e ao progresso, de modo que ela normalmente é descrita como atrasada, isolada e pobre. Entretanto, ao longo dessa pesquisa podemos verificar que o acesso à ideologia e a adoção dessas práticas não necessariamente têm relação com o desconhecimento, o isolamento ou a falta de recursos materiais, mas sim com as escolhas de consumo desse grupo doméstico e com a adequação desse processo à realidade local.

A análise da louça fundamentou as informações acerca das preferências alimentares piauienses. A maior parte dos itens analisados pertenciam a formas planas, principalmente pratos, corroborando com o consumo de itens mais sólidos, como a Maria Isabel, o Baião de Dois, a paçoca de carne e os assados. Os itens côncavos como malgas e tigelas pequenas sugerem o consumo de pratos pastosos como a coalhada e os doces de calda também presentes na alimentação cotidiana dos grupos de elite. Outros artefatos côncavos como as xícaras estavam associados ao consumo majoritário do café.

Além disso, podemos afirmar que a ruralidade piauiense e a importância que as fazendas de gado tiveram para a formação desse Estado permanecem mesmo na contemporaneidade. A chamada "culinária típica” tem suas origens nas fazendas de gado onde os pratos tinham como base a carne vermelha tanto de boi quanto de porco e criação, em menor proporção, de aves, como a galinha caipira e o capote (galinha d'angola), as frutas, 
os cerais como o milho e o arroz e a farinha de mandioca que são ingredientes básicos de pratos como a Maria Izabel, a paçoca, o pirão de parida e a cajuína, consumidos em praticamente todo território piauiense e por isso considerados típicos (Silva, 2015)

Podemos perceber, desse modo, que o passado colonial está fortemente ligado com a memória e as tradições culturais de muitos piauienses. Nesse contexto da memória afetiva, as comidas se tornam mediadoras dessa relação, revelando sentimentos não apenas entre aquilo que se come, mas entre os que comem (Silva, 2013).

Os dados levantados nessa pesquisa também contribuíram com a compreensão de que esse grupo desenvolveu formas próprias de se integrar à modernidade, não deixando de consumir itens manufaturados como as louças de origem inglesa, mas adequando-as à sua realidade; adquirindo itens com uma preocupação mais funcional para o cotidiano e louças mais caras para as ocasiões que exigiam mais formalidade, como as festas de casamento ou outras festividades, sem adotar plenamente os valores de um modo de vida com a qual eles não se identificavam.

Podemos afirmar, assim, que apesar das atividades comerciais pouco desenvolvidas, do isolamento e das demais dificuldades que se possa considerar, a sociedade piauiense, principalmente a elite, tinha acesso aos produtos que circulavam no comércio brasileiro, incluindo os itens importados. Todavia esses produtos considerados símbolos de luxo e riqueza não possuíam a mesma importância para a elite piauiense, que buscava demonstrar suas posses de outras maneiras, nos permitindo concluir que a adoção das práticas e consequentemente dos objetos diagnósticos da modernidade, dentre eles a louça, foram pautados em escolhas e não em fatores secundários como acesso, conhecimento ou poder aquisitivo.

As louças de Prazeres, os inventários post mortem, as estruturas edificadas encontradas no sítio e os demais dados históricos levantados sugerem que esse grupo doméstico fez escolhas de consumo que orientaram seu paladar, o qual estava amarrado a uma série de tradições e modos particulares de compartilhar comida. Mantendo viva suas tradições, inseriram-se nos hábitos da Nova Cozinha, sem, contudo, abandonar antigas formas de preparar e servir as refeições. As louças, nesse contexto, demonstraram associações com os ideais modernos, mas a escolha desses itens também estava pautada nas particularidades regionais.

\section{AgRADECIMENTOS}

Agradeço às minhas orientadoras, professora Dr ${ }^{\mathrm{a}}$ Maria do Amparo Alves de Carvalho e Dr ${ }^{\mathrm{a}}$ Fernanda Codevilla Soares, por aceitarem me guiar nessa pesquisa, me auxiliando na escolha do tema, em todas as etapas de construção da dissertação e na elaboração deste artigo. Aos proprietários e atuais moradores da Fazenda Prazeres, pela disponibilidade em sempre nos receber e pelas informações que nos auxiliaram muito em campo. Às equipes de escavação. Ao professor Dr. Fonseca Neto, Dra Jacionira Coelho e Dra María Marschoff, pelas contribuições durante as bancas de qualificação e defesa. Ao Reginaldo Miranda, por ter fornecido informações e fontes bibliográficas essenciais para esse trabalho. 


\section{REFERÊNCIAS BIBLIOGRÁFICAS}

ARAÚJO, M. L. V. 2004.Os interiores domésticos após a expansão da economia exportadora paulista. Anais do Museu Paulista. 12:129-160.

ARAÚJO, A. G. \& CARVALHO, M. R. R. 1993. A louça inglesa no século XIX: considerações sobre a terminologia e metodologia utilizadas no sítio Florêncio de Abreu, São Paulo. Revista do MAE. 3:81-95.

BARBOSA, Rute Ferreira. 2012. "Para o povo ver”: A materialidade dos Engenhos Banguês do Norte de Alagoas. Dissertação de Mestrado em Arqueologia. Universidade Federal de Pernambuco.

BRANDÃO, Tanya Maria Pires. 1995. A elite colonial piauiense: família e poder. Teresina: Fundação Monsenhor Chaves.

BRAUDEL, F. 1997.O supérfluo e o costumeiro: alimentos e bebidas. Em: BRAUDEL, F. Civilização Material, Economia e Capitalismo, séculos XV-XVIII. Martins Fontes. São Paulo. 161-301.

CONTRERAS, J. e GRACIA, M. 2011.Alimentação, sociedade e cultura. Fiocruz, Rio de Janeiro.

COSTA, Sebastião Martins de Araújo Costa. 1954. Dados Genealógicos da Família Rocha. $1^{\text {a }}$ edição, Rio de Janeiro.

COSTA, Sebastião Martins de Araújo Costa; ROCHA, Moacyr Sipaúba da; REZENDE, José Ferreira de Sousa. 1999. Dados Genealógicos da Família Rocha. $3^{a}$ edição, Teresina.

CRUZ, M. Aproximaciones a las prácticas alimentícias de los grupos foqueros (Islas Shetland del Sur, siglo XIX). 2011. Monografia (Graduação em Arqueologia). Facultad de Filosfía y Letras, Universidad de Buenos Aires, Buenos Aires.

FALCI, Miridan Knox. 2007. Mulheres no Sertão Nordestino. In.: DEL PRIORE, Mary (Org.). História das Mulheres no Brasil. São Paulo: Contexto.

FONSECA NETO, Antonio dos Santos. 2016. Sertanias. 1. ed. Teresina: Academia Piauiense de Letras.

GARDNER, George. 1975. Viagem ao interior do Brasil, principalmente nas províncias do Norte e nos distritos do ouro e do diamante durante os anos de 1836-1841. Ed. Itatiaia, São Paulo.

GOULART, José Alípio. 1965. O Brasil do boi e do couro. Rio de Janeiro: Edições GDR.

HABITUS. 2014. $3^{\circ}$ Relatório Parcial do Programa de Resgate Arqueológico no trecho da BR 135 entre os municípios de Bertolínia e Eliseu Martins, no Estado do Piauí.

IBGE CIDADES. Acessado em 10 de dezembro de 2018, em https: / / cidades.ibge.gov.br/.

LIMA, T.A. 1989. A tralha doméstica em meados do século XIX: reflexos da emergencia da pequeña burguesía do Rio de Janeiro. Dédalo, v.1, p.205-30, Publicação Avulsa.

LIMA, T.A. 1995. Pratos e mais pratos: louças domésticas, divisões culturais e limites sociais no Rio de Janeiro, século XIX. Anais do Museu Paulista. 3: 129-191.

LIMA, T. A. 1996. Humores e odores: ordem corporal e ordem social no Rio de Janeiro, no século XIX. História, Ciência, Saúde - Manguinhos. Rio de Janeiro: Fundação Oswaldo Cruz. 44-96.

LIMA, T. A. 1997. Chá e simpatia: uma estratégia de gênero no Rio de Janeiro oitocentista. Anais do Museu Paulista. 5:93-127. 
O “DICUMÊ” ESTÁ PRONTO! A INFLUÊNCIA DAS PRÁTICAS ALIMENTARES DA NOVA COZINHA NO COTIDIANO DOS HABITANTES DA FAZENDA PRAZERES -BERTOLÍNIA, PIAUÍ

LIMA, T. A. 1999. El huevo de la serpiente: uma arqueologia del capitalismo embrionário em el Río de Janeiro del siglo XIX. Em: ZARANKIN, A. e ACUTO, F. (eds) Sed Non Satiata: Teoria Social em la Arqueología Latinoamericana Contemporánea. Ediciones del Tridente. Buenos Aires. 189-238.

MAJEWSKI, T. e O'BRIEN.1987. The use and misuse of nineteenth-century english and american ceramics in archaeology analysis. Advances in archaeological method and theory. Vol.11:97-209.

MARSCHOFF, María. 2004. Gato por liebre: Prácticas alimenticias en Floridablanca. Tesis de Licenciatura em Ciências Antropológicas, Universidade de Buenos Aires.

MARSCHOFF, María. 2007. ¿Comer o Nutrirse? La Alimentación Como Práctica Social. Arqueología 13: 155-184.

MARSCHOFF, María. 2010. De la cocina al comedor: pensar y estudiar la alimentación del pasado. Disponível em: http: / /www.unpocodehistoria.com/monografias.

MARSCHOFF, María. 2011. El cuerpo y la corporización como herramientas metodológicas para el estúdio de la cultura material. Temas y problemas de la Arqueología Histórica. Tomo II. Universidad Nacional de Luján, Luján. Pp. 369-382.

MARSCHOFF, María. 2013.Los objetos de la alimentación en el Buenos Aires virreinal: entre el mercado mundial y las prácticas cotidianas. Revista de Arqueología Histórica Argentina y Latinoamericana 7:11-40. Buenos Aires.

MATOS, Matias Augusto de Oliveira. 2007. Pelas quebradas, várzeas e chapadas: uma viagem gastronômica pelo Piauí. 2 ed. Teresina: Alínea Publicações.

MIRANDA, Reginaldo. 1996. Bertolínia: história, meio e homens. 2ed.Teresina: COMEPI.

MIRANDA, Reginaldo. 2017. Memória dos ancestrais - parentes e contraparentes: uma genealogia do Sertão. Teresina: Academia Piauiense de Letras.

MOTT, Luiz R. B. 1995. Piauí colonial: população, economia e sociedade. Teresina: Projeto Petrônio Portella.

OLIVEIRA, Ana Joaquina da Cruz. 2018. A Comida Está Servida! Um Estudo das Práticas Alimentares Na Fazenda Prazeres, Bertolínia - Pi. Dissertação de Mestrado, Universidade Federal do Piauí.

PEIXOTO, L. S. 2008. Louças e modos de vida urbano na Pelotas oitocentista. Mestrado em Memória Social e Patrimônio Cultural. Instituto de Ciências Humanas. UFPEL. Pelotas. 164pp.

PESSOA, Jordânia Maria. 2007.Entre a Tradição e a Modernidade: A Belle Époque Caxiense: Práticas fabris, reordenamento urbano e padrões culturais no final do século XIX. Dissertação de Mestrado em História do Brasil, Universidade Federal do Piaui.

PORTO, Carlos Eugenio. 1974. Roteiro do Piaui. Editora: Artenova.

SILLIMAN, S. e HALL, M. 2006. Introduccion: Archaeology of Modern World. In: SILLIMAN, S. e HALL, M. (orgs) Historical Archaeology. Blackwell, United Kingdom. Pp.1-22.

SILVA, Josias Clarence Carneiro da1991. Abelheiras: Último reduto da Casa da Torre no Piauí — Um estudo de história social. Teresina: Gráfica Júnior.

SILVA, Samara Mendes Araújo. 2013. DA FAZENDA PARA CIDADE: traços da cultura material e imaterial sertaneja nas casas piauienses em fins do século XX. Anais do XXVIII Simpósio Nacional de História. Natal, RN.

SILVA, Samara Mendes Araújo. 2015. A regionalidade de algumas comidas brasileiras: um estudo das comidas sertanejas no século XX. In: Cilene da Silva Gomes Ribeiro; Carmen Soares. (Org.). Odisseia de Sabores da 
Lusofonia. 1ed.CURITIBA-PR/LISBOA-PORTUGAL: Imprensa da Universidade de Coimbra e PUCPRESS, v. 01 , p. 265-284

SYMANSKI, L.C.P. 2002. Louças e auto-expressão em regiões centrais, adjacentes e periféricas do Brasil. In: Arqueologia da Sociedade Moderna na América do Sul: Cultura Material, Discursos e Práticas, ed. by Andrés Zarankin e Maria Ximena Senatore. Buenos Aires, ediciones del Tridente, pp.31-62.

SYMANSKI, L. C. P. 1997. Grupos domésticos e comportamento de consumo em Porto Alegre no século XIX: o Solar Lopo Gonçalves. Dissertação de Mestrado em História. Faculdade de Filosofia e Ciências Humanas. PUCRS. Porto Alegre. 212pp.

SYMANSKI, L. C. P.2002. Louças e Auto-Expressão em Regiões Centrais, Adjacentes e Periféricas do Brasil. In: Arqueologia da Sociedade Moderna na América do Sul: Cultura Material, Discursos e Práticas, ed. by Andrés Zarankin e Maria Ximena Senatore. Buenos Aires, ediciones del Tridente, pp.31-62

SOARES, F. C. 2011.Vida material de Desterro no século XIX: as louças do Palácio do Governo de Santa Catarina. Universidade de Trás-os-Montes e Alto Douro, Vila Real.

SOARES, F. e CORÇÃO, M. 2012. Bom Gosto à Mesa: Cultura Material e Distinção Social no Brasil do Século XIX. Clio Arqueológica. N.2, v.27: s/p. Recife

SOARES, F. C. 2016. Comida, Cultura e Sociedade Arqueologia da alimentação no Mundo Moderno. In: Comida, Cultura e Sociedade Arqueologia da alimentação no Mundo Moderno.

SOUZA, RAFAEL A. 2015. Globalização, consumo e diacronia: populações sertanejas sob a ótica arqueológica. Vestígios Revista Latino-Americana de Arqueologia Histórica.-. V. 9 N. 2.

TOCChETTO, F. B.; SYMAnSKI, L. C. P.; OZÓRIO, S. R., OllVEIRA, A. T. D. 2001. A Faiança Fina em Porto Alegre: vestígios arqueológicos de uma cidade. Secretaria Municipal de Cultura. Porto Alegre.

TOCCHETTO, F. B. 2010. Sobre práticas cotidianas na Porto Alegre moderna oitocentista. Oikos. São Leopoldo. 